\title{
MISLEADING FREE T4 DUE TO AUTO-T4 ANTIBODIES RESULTING IN ABNORMAL THYROID FUNCTION TESTS: A CASE REPORT
}

\section{Karuppiah, S I Majitha, S Dilakkumar, M Pravinson}

Teaching Hospital Batticaloa, SriLanka.

\section{ABSTRACT}

Introduction: The presence of elevated TSH with high free T4 is considered as an abnormal thyroid function test. This may be due to false elevation of serum T4 associated with autoantibodies to T4. We report a case that presented with high serum freeT4 and TSH associated with autoantibodies to T4.

Case presentation: A 40 year old female patient presented with tiredness and sweating. She was diagnosed with primary hypothyroidism two years ago based on elevated TSH. She was treated with thyroxine $50 \mathrm{mcg}$ per day for 6 months and then she was defaulted. Examination revealed a thin lady with BMI of $18.5 \mathrm{Kgm}^{-2}$ with a mild goiter. She was otherwise clinically euthyroid. Investigations revealed abnormal thyroid function test (TFT) with TSH of $43.6 \mathrm{mIU} / \mathrm{l}$ and freeT4 of 3.06ng/dl. Her TFT was repeated on three laboratories which showed elevated TSH and upper normal to elevated freeT4. She had high titres of anti thyroid peroxidase (TPO antibodies) $>1300 \mathrm{mIU}$. Her thyroid scan revealed small multinodular goiter and fine needle aspiration cytology confirmed Hushimoto's thyroiditis. In view of the clinical findings the following possibilities were considered; assay interference, TSHoma and thyroid hormone resistance. TSHoma seemed less likely due to normal pituitary gland on MRI and normal SHBG. Further analysis of the sample was done with comparison between one step and two step methods using Cantaur and Delfia assays respectively. There was no evidence of assay interference in respect of TSH (38.73 vs $44.1 \mathrm{mIU} / \mathrm{l}$ ) and free T3 (3.9 vs $5.3 \mathrm{pmol} / \mathrm{l}$ ), however the freeT4 measurements were not consistent across the two platforms ( 25.6 vs $11.8 \mathrm{pmol} / \mathrm{l})$. In addition, the total T4 measurement was elevated (219nmol/l; normal range 69-141) with $32 \%$ recovery after PEG treatment. Taken together, the results were suggestive of autoimmune hypothyroidism with evidence of freeT4 (and total T4) assay interference due to anti-T4 autoantibodies. The patient was treated with thyroxine and thereafter monitored using a TSH assay alone to guide treatment adequacy.

Conclusions: Clinicians must be aware of possible assay interference including the measurement of freeT4 in the differential diagnosis of abnormal TFT that do not fit the patient's clinical presentation

Key words: abnormal thyroid function, autoantibodies, FreeT4 assay interference.

\section{CASE PRESENTATION}

A 40 year old single female patient presented with tiredness and sweating. She was diagnosed with primary hypothyroidism two years ago based on elevated TSH. She was treated with thyroxine $50 \mathrm{mcg}$ per day for 6 months and then she was defaulted. She did not report any headache, visual problems, excessive sweating or dizzy episodes. Her bowel habits were normal. She had regular menstrual periods and did not complain menorrhagia. Apart from mild bronchial asthma she did not have any significant personal or family history. She was a nonsmoker and did not consume alcohol. Examination revealed thin lady with BMI of $18.5 \mathrm{Kgm}^{-2}$ with a mild goiter. She was otherwise clinically euthyroid (Figure 1).
Figure 1

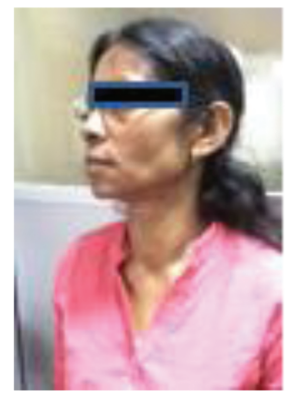

Investigations revealed abnormal thyroid function test (TFT) with TSH of $43.6 \mathrm{mIU} / \mathrm{l}$ and FT4 of $3.06 \mathrm{ng} / \mathrm{dl}$. Other hormonal profile and biochemical tests were shown in table 1 . Her TFT was repeated to confirm the findings on three separate laboratories

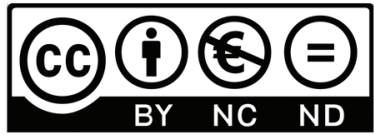


with different platforms which was shown in table 2 . She had high titres of anti thyroid peroxidase (TPO antibodies) > 1300mIU. Her thyroid scan confirmed small multinodular goiter with largest nodule of $3.9 \times 2.3 \mathrm{~cm}$. Fine needle aspiration cytology (FNAC) of the nodule showed clusters of Hurtheloid cells with scattered multi nuclear giant cells, lymphocytes and plasma cells suggestive of Hushimoto's thyroiditis (Thy 2, Bethesda 2).

She had elevated TSH in all tests with variable FT4 between upper normal to high levels for the reference range. In view of the clinical findings the following possibilities were considered; assay interference, TSH producing tumour and thyroid hormone resistance.
Although she complained of excessive sweating and had a low BMI, her MRI (magnetic resonance image) of pituitary showed normal size pituitary gland (Figure 2). In addition, she had normal SHBG. In this context, TSH secreting pituitary adenoma deemed less likely and other two entities need exclusion.

Due to lack of availability of further specific investigations in our institute, patient's blood sample was send to the metabolic research laboratories, Addenbrooke's hospital, Cambridge. Further analysis of the sample was done with comparison between one step and two step methods using Cantaur and Delfia

\section{Table 1}

\begin{tabular}{|l|l|l|}
\hline Tests & Results & Normal Range \\
\hline Haemoglobin & 12.4 & $12-15 \mathrm{~g} / \mathrm{dl}$ \\
Serum Creatinine & 0.7 & $0.8-1.3 \mathrm{mg} / \mathrm{dl}$ \\
Fasting blood glucose & 88 & $65-100 \mathrm{mg} / \mathrm{dl}$ \\
Total cholesterol & 241 & $<225 \mathrm{mg} / \mathrm{dl}$ \\
LDL cholesterol & 120 & $80-125 \mathrm{mg} / \mathrm{dl}$ \\
Triglyceride & 179 & $50-150 \mathrm{mg} / \mathrm{dl}$ \\
9 AM Cortisol & 297 & $100-500 \mathrm{nmol} / \mathrm{l}$ \\
FSH & 3.48 & $1-10 \mathrm{mIU} / 1$ \\
LH & 10.6 & $1-10 \mathrm{mIU} / \mathrm{l}$ \\
Prolactin & 376.7 & $50-500 \mathrm{mIU} / \mathrm{l}$ \\
SHBG & 78 & $40-120 \mathrm{nmol} / \mathrm{l}$ \\
\hline
\end{tabular}

\section{Table 2}

\begin{tabular}{|c|c|c|c|c|}
\hline & Lab1 & Lab 2 & Lab 3 & Lab 4 \\
\hline Platform / Method & $\begin{array}{l}\text { VIDAS } \\
\text { Enzyme linked } \\
\text { fluorescent assay } \\
\text { One step }\end{array}$ & $\begin{array}{l}\text { Seimens Immulite } \\
\text { Solid phase, } \\
\text { enzyme labelled } \\
\text { chemiluminescent } \\
\text { competitive } \\
\text { immune assay } \\
\text { One step }\end{array}$ & $\begin{array}{l}\text { VITROS } \\
\text { Direct labelled } \\
\text { antibody } \\
\text { competitive } \\
\text { immune assay }\end{array}$ & $\begin{array}{l}\text { ELFA } \\
\text { Enzyme linked } \\
\text { fluorescent assay }\end{array}$ \\
\hline TSH & $43.6 \mathrm{mIU} / \mathrm{l}(0.5-5)$ & $40.5 \mathrm{mIU} / \mathrm{l}(0.5-5)$ & $33.1 \mathrm{mIU} / \mathrm{l}(0.5-5)$ & $38.34 \mathrm{mIU} / \mathrm{l}(0.5-5)$ \\
\hline FT4 & $3.06 \mathrm{ng} / \mathrm{dl}(0.9-2)$ & $19.9 \mathrm{pmol} / \mathrm{l}(9-20)$ & $12.8 \mathrm{pmol} / \mathrm{l}(10-19)$ & $16.01 \mathrm{pmol} / \mathrm{l}(9-20)$ \\
\hline FT3 & & & & \\
\hline
\end{tabular}


Figure 2

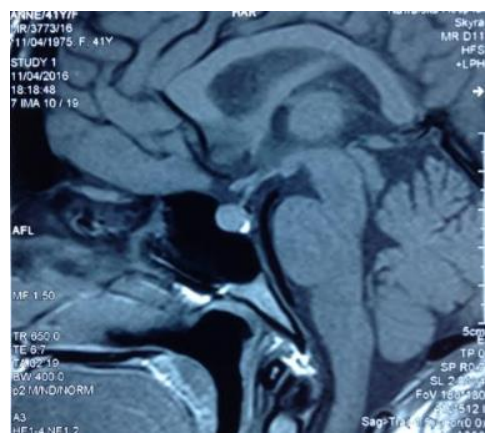

assays respectively (table 3). There was no evidence of assay interference in respect of TSH (38.73 vs $44.1 \mathrm{mIU} / \mathrm{l}$ ) and free T3 (3.9 vs $5.3 \mathrm{pmol} / \mathrm{l}$ ), however the freeT4 measurements were not consistent across the two platforms (25.6 vs $11.8 \mathrm{pmol} / \mathrm{l}$ ). In addition, the total T4 measurement was elevated $(219 \mathrm{nmol} / \mathrm{l}$; normal range 69-141) with 32\% recovery after PEG treatment.

Taken together, the results were suggestive of autoimmune hypothyroidism with evidence of freeT4 (and total T4) assay interference due to anti-T4

\section{Table 3}

\begin{tabular}{|c|c|c|}
\hline & $\begin{array}{l}\text { ADVIA Centaur assay } \\
1 \text { step test }\end{array}$ & $\begin{array}{l}\text { Delfia assay } \\
2 \text { step test }\end{array}$ \\
\hline TSH (mU/L) & 38.73 & $\begin{array}{l}\mathbf{4 4 . 1 0} \\
(0.4-4.0) \\
\text { Linear to Dilution and normal } \\
\text { PEG recovery }\end{array}$ \\
\hline Reference Range & $(0.35-5.5)$ & \\
\hline FT4 (pmol/L) & 25.6 & 11.8 \\
\hline Reference Range & $(10-19.8)$ & $\begin{array}{l}(9-20) \\
\text { Linear to Dilution and normal } \\
\text { PEG recovery }\end{array}$ \\
\hline FT3 (pmol/L) & 3.9 & 5.3 \\
\hline Reference Range & $(3.5-6.5)$ & $(3.0-7.5)$ \\
\hline Total T4 (nmol/L) & & 219 \\
\hline Reference Range & & $\begin{array}{l}(69-141) \quad \\
32 \% \quad \text { Recovery } \quad \text { with } \quad \text { PEG } \\
\text { precipitation; } \\
\text { suggesting possible assay interference }\end{array}$ \\
\hline TBG (ug/ml) & & 17.9 \\
\hline Reference Range & & $(14-31)$ \\
\hline Anti TPO Antibody & & $>1300$ \\
\hline Reference Range & & $(0-60 \mathrm{mIU})$ \\
\hline
\end{tabular}


autoantibodies. The patient was treated with thyroxine and thereafter monitored using a TSH assay alone to guide treatment adequacy. Two months after treatment her TSH went down to $2.3 \mathrm{mIU} / \mathrm{l}$ confirming the diagnosis.

\section{DISCUSSION}

Thyroid function evaluation usually includes measurement of TSH and free or total thyroxine (T4 and T3). Majority of patients' clinical picture is consistent with thyroid function evaluation. However in some circumstances there may be discordant results which is inconsistent with the patients' signs and symptoms. When a patient presented with unusual thyroid test and the clinical presentation and the test results do not fit well, it is important to consider other rare possibilities. Our patient presented with elevated TSH and variable levels of free T4. Elevated TSH with elevated or non supressed free T4 will be a result of TSH secreting pituitary adenoma, resistance to thyroid hormone (RTH) or laboratory artefact.

TSH secreting pituitary adenomas (TSHomas) are characterized by high levels of circulating free thyroid hormones (FT4 and FT3) in the presence of nonsupressed serum TSH concentrations (1). Most of the patients have a long history of hyperthyroidism and uni or multinodular goiter is described in the majority $(2,3)$. Although our patient had increased sweating, a mild multinodular goiter and low BMI, TSHoma was excluded by a normal pituitary gland on MRI, normal SHBG and thyroid function test showing false elevation of FT4 with two step assay.

RTH is characterised by a reduced responsiveness of target tissues to thyroid hormone due to mutations on the thyroid hormone receptor beta gene (4). Patients with RTH are generally euthyroid. However, in a minority of patients who have predominant central or pituitary resistance, thyrotoxic features have been described (5). Common features of RTH includes goitre, but they may infrequently have tachycardia, hyperkinetic behaviour, cardiac abnormalities, auditory disorders, low body weight, language disabilities and subnormal intelligence (6). In our patient, the presence of goitre and low body weight are consistent with this diagnosis, as is the elevated
TSH and FT4. However, TSH is only mildly elevated or in the upper half of the reference range in RTH. Our patient had TSH of more than $30 \mathrm{mu} / \mathrm{l}$. The other fact should be considered is the level of FT3. Patients with RTH should have elevated FT3 in proportion to FT4 whereas this patient had normal FT3.

The combination of elevated TSH and elevated FT4 in our patient raised the possibility of laboratory artefact. Although it is generally considered that FT4 assays are more reliable than the old fashioned total $\mathrm{T} 4$ assay, it is questionable in some occasions (7). The analog methods are generally used in FT4 assays where a labelled T4 analog competes with the serum FT4 for binding to an antibody. The commonly available methods in Sri Lanka employ one step immuno assay. While one step assay is affected by thyroid hormone autoantibodies, which directly compete with endogenous FT4, a two-step assay using an additional washing step induces a noncompetitive reaction that removes the unbound FT4 and interfering factors (8). Non-specific binding of heterophile antibodies, thyroid autoantibodies or rheumatoid factor may interfere with thyroid hormone measurement. The prevalence of anti T4 and T3 antibodies in the general population is estimated to be $10 \%$ and in autoimmune thyroid disease about $40 \%$ (9). This patient had very high titres of anti-TPO antibodies. Autoantibodies to thyroid hormones may lead to abnormal FT4 by interference with the one step tests $(9,10)$. This also causes artefacts in total T4 measurement.

The patient's sample was checked on various laboratories in our country (VIDAS, IMMULITE, VITROS, ELFA) but all methods used one step tests. These showed upper normal to elevated FT4. When thyroid function test was repeated in two step test using Delfia assay, the FT4 level was not increased. This suggested that FT4 in one step assay was falsely elevated, point towards the possibility of the presence of anti T4 antibody. The direct tests to detect heterophil antibodies were not available in our department. Therefore the exact nature of interfering substance is not known in our patient. But the overall clinical picture is suggestive of auto immune hypothyroidism with evidence of freeT4 (and total T4) assay interference due to anti-T4 autoantibodies. 


\section{CONCLUSION}

This case emphasize the importance of cautious interpretation of thyroid function test when there is discrepancy between clinical picture and laboratory results. Clinicians must be vigilant to the possibility of antibodies to FT4 in the presence of autoimmune thyroid disease. Support of chemical pathologist will help to avoid unnecessary time consuming investigations and guide proper management of patients.

\section{REFERENCES}

1. Beck-Peccoz P, Lania A, Beckers A, Chatterjee K, and Wemeau JL. European Thyroid Association Guidelines for the Diagnosis and Treatment of Thyrotropin-Secreting Pituitary Tumors. Eur Thyroid J 2013 Jun; 2(2): 76-82.

2. Beck-Peccoz P, Persani L, Mannavola D, Campi I. Pituitary tumours: TSH-secreting adenomas. Best Pract Res Clin Endocrinol Metab. 2009 Oct; 23(5):597-606.

3. Brucker-Davis F, Oldfield EH, Skarulis MC, Doppman JL, Weintraub BD. Thyrotropinsecreting pituitary tumors: diagnostic criteria, thyroid hormone sensitivity, and treatment outcome in 25 patients followed at the National Institutes of Health. J Clin Endocrinol Metab 1999 Feb; 84(2):476-86.

4. Rivas AM, Lado-Abeal J. Thyroid hormone resistance and its management. Proceedings (Baylor University Medical Center) 2016; 29(2):209-211.

5. Moran C, Chatterjee K. Resistance to thyroid hormone due to defective thyroid receptor alpha. Best Practice \& Research Clinical Endocrinology \& Metabolism. 2015; 29(4):647-657. (doi:10.1016/j.beem)

6. Resistance to thyroid hormone, Oxford handbook of endocrinology and diabetes, third edition published 2014.

7. Klisiewicz AM, Rambau PD, Distiller LA Euthyroid hyperthyroxinaemia due to assay interference. Journal of Endocrinology, Metabolism and Diabetes of South Africa. 2011; 16(3):155-158

8. Mi-Na Lee, Soo-Youn Lee, Kyu Yeon Hur, HyungDoo Park. Thyroxine (T4) Autoantibody Interference of Free T4 Concentration Measurement in a Patient With Hashimoto's Thyroiditis. Ann Lab Med. 2017 Mar; 37(2): 169171.

9. Gülșah Elbüken, Züleyha Karaca, Fatih Tanrıverdi, Kürșad Unluhizarci, Samuel Refetoff, Fahrettin Keleștimur Circulating Antibodies to
T4 Causing Discordant Tests of Thyroid Function: A Case Report. Turk Jem 2014; 1: 19-22.

10. Tanikawa T, Okada Y, Zeki K, Kanda K, Morita E, Tanaka Y. A case of hypothyroidism due to hashimoto disease that presented elevations of free $\mathrm{T} 3$ and free $\mathrm{T} 4$ by thyroid hormone autoantibodies. Jornal of UOEH 2002; 24:423-7. 